\title{
Reef-building properties of Tubastraea micranthus (Scleractinia, Dendrophylliidae), a coral without zooxanthellae
}

\author{
H. Schuhmacher \\ Universität GHS Essen, FB 9 - Hydrobiologie, D-4300 Essen, Federal Republic of Germany
}

\begin{abstract}
One characteristic of reef-building corals is a skeletal strength sufficient to endure hydrodynamic stress. Porosity, compressive and bending strength, elastic modulus and resistance to abrasion were measured in the reef-inhabiting colonial dendrophylliids Tubastraea micranthus and $T$. aurea and in the acroporids Acropora palmata and A. cervicornis. Dendrophylliids are devoid of zooxanthellae, acroporids possess zooxanthellae and are well recognized reef-builders. The mechanical properties of $T$. micranthus colonies, collected in Philippine reefs, equal or even surpass those of the acroporids, which rank at the high-strength end of the porosity / strength continuum. Skeletal strength and colony form set out $T$. micranthus as a primary framework-builder (sensu Goreau, 1963), corroborating field observations on Philippine reefs. Therefore the conventional affiliation of $T$. micranthus to the 'ahermatypic' category (sensu Wells, 1933) is not functionally correct. The respective data of $T$. aurea, however, show that this species has little significance as a reef-builder.
\end{abstract}

\section{INTRODUCTION}

Reef-building capacity depends on the ability to endure hydrodynamic stress. From this point of view Chamberlain (1978) and Schuhmacher (1981) discussed the ecological role of mechanical properties of a variety of coral skeletons; their adaptive significance versus morphological design was examined by Graus et al. (1977) and Schuhmacher and Plewka (1981a); the relative importance of skeletal strength through geological time was discussed by Schuhmacher and Plewka (1981b) and the obvious change in colony strength through boring sponges was the matter of a paper by Tunnicliffe (1979). The scleractinians studied by these authors are all reef-building and possess zooxanthellae.

A current distinction separates 'hermatypic' corals as reef-building, shallow water forms from 'ahermatypic' corals which are not reef-building and not restricted to shallow depths. This classification goes back to Wells (1933) who not only coined the terms but also equated 'hermatypic' with possessing zooxanthellae and 'ahermatypic' with being devoid of these symbiotic algae.

The present study compares the reef-building capacity of the colonial dendrophylliids Tubastraea micranthus (Ehrenberg) and T. aurea (Quoy and Gaimard) with that of the acroporids Acropora palmata (Lamarck) and A. cervicornis (Lamarck). According to Wells' definition, which emphasizes the importance of zooxanthellae, these dendrophylliids would conventionally be grouped with the ahermatypic corals, since they lack zooxanthellae. The acroporids (with zooxanthellae), on the other hand are affiliated with the hermatypic category. They are major reef-building corals and rank at the high-strength end of the porosity/ strength continuum. This study contributes to the bionomy of $T$. micranthus and, by a detailed evaluation of the relevant mechanical properties, intends to throw new light on the conventional separation of 'hermatypes' and 'ahermatypes' as practised in extant literature.

\section{MATERIAL}

The systematic position of what is called in this paper Tubastraea micranthus (Ehrenberg) and T. aurea (Quoy and Gaimard) has long been uncertain (see below) and still requires thorough revision. At least in the case of $T$. micranthus the occasional affiliation with the genus Dendrophyllia may have been suggested by the arborescent growth form. The septal arrangement, however, which was used by Vaughan and Wells 
(1943) to discern the 2 genera, obviously classifies our material into the genus Tubastraea (no Pourtalès plan).

A selected list of synonyms of Tubastraea micranthus comprises:
Oculina micranthus:

Dendrophyllia nigrescens:

Cönopsammia micranthus:

Dendrophyllia micranthus:

Dendrophyllia micranthus:

Dendrophyllia micranthus:

Dendrophyllia micranthus var. grandis:

Dendrophyllia micranthus:

Tubastraea micranthus:

Tubastraea micrantha:

Tubastraea micranthus:
Ehrenberg, 1834: 304

Dana, 1846: 387

Klunzinger, 1879: 2; 58

van der Horst, 1922: 101 (with synonymy)

van der Horst, 1926: 1

Faustino, 1927: 218

Crossland, 1952: 173

Nemenzo, 1960: 16

Pichon, 1978: 422, 441

Rosen, 1979: 20

Scheer \& Pillai, 1983: 175
Tubastraea micranthus occurs from the Red Sea through the Indian Ocean to the Comores and Madagascar, and to the Fiji Islands in the Pacific Ocean; $T$. nigrescens Dana is considered here as the main synonym. The species is conspicuous in the reef by its dark-green to brownish-black soft tissue. Unlike most other members of the family which grow under overhangs and in caves on the reef, specimens of $T$. micranthus in the Philippines were also found from 4 to $50 \mathrm{~m}$ depth growing fully light-exposed as other reef corals. Here the colonies grow up to $1 \mathrm{~m}$ high and to 15 $\mathrm{cm}$ diameter at the stem base. Usually colonies are fanshaped with 1 to $3 \mathrm{~cm}$ thick branches perpendicular to the prevalent current (Fig. 1).

In the Red Sea, however, colonies observed by the author are much smaller. They were found only in the dim light under ledges of the reef slope down to $12 \mathrm{~m}$. Surveys by a submersible of the deep forereef in the Gulf of Aqaba between 50 and $200 \mathrm{~m}$ depth (Fricke and Schuhmacher, 1983) never encountered Tubastraea micranthus colonies. Whereas specimens from shallow depths of the central Red Sea (Port Sudan area) still reached $25 \mathrm{~cm}$ length, the many colonies found at similar places in the northern and southern Gulf of Aqaba did not exceed $12 \mathrm{~cm}$. However, one single colony of $42 \mathrm{~cm}$ height and $33 \mathrm{~cm}$ width was found in $30 \mathrm{~m}$ depth near Aqaba during the cooperative FrenchJordanian coral reef research program (Dr. Zibrowius, pers. comm.).

In general, a decrease in size can be stated from Philippine to Red Sea forms, when colonies from shallow depths are compared. Correspondingly there is also a decrease in calcification and skeleton-strength. Heavily calcified, low-porous skeletons, common on Philippine reefs, were never recorded by the author in the Red Sea. The Gulf of Aqaba specimens are especially weak. This is also true if equally sized branch tips from both localities are compared. Hence Tubastraea micranthus must be regarded as a very variable species. Crossland (1952) who was familiar with Red Sea as well as with West Pacific forms, even hesitated to unify both in one species. The following experimental study and discussion focus on Philippine material only. A systematic revision is also needed for what should be comprised by $T$. aurea. The selection of synonyms hereinafter does not pretend to be such an attempt, it mainly follows Scheer and Pillai (1983): Lobophyllia aurea:

Quoy \& Gaimard, 1833: 195
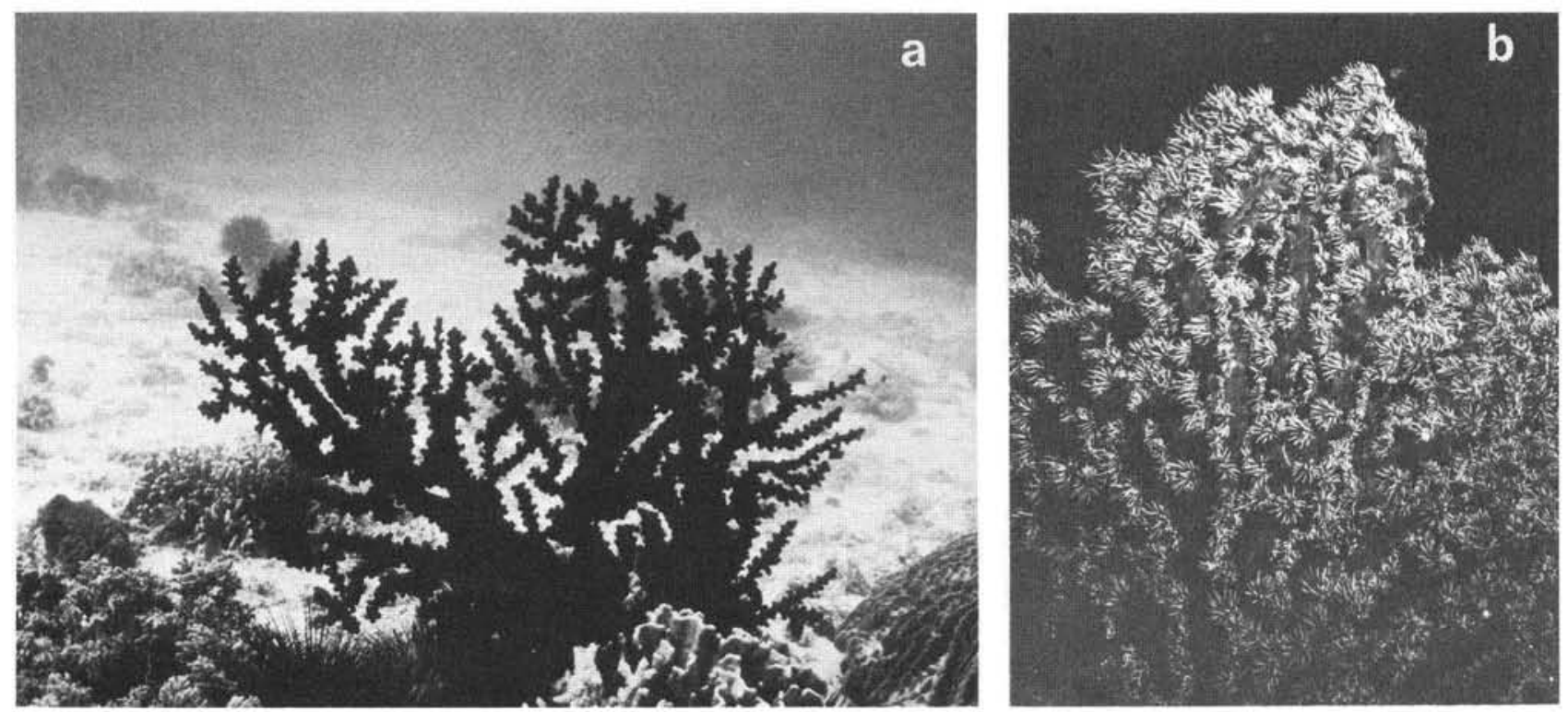

Fig. 1. Tubastraea micranthus. Colony at Sumilon Island (Negros, Philippines), $8 \mathrm{~m}$ water depth; (a) during day; (b) polyps expanded at night 
Tubastraea coccinea:

Coenopsammia ehrenbergiana:

Lesson, 1834: 515

Milne Edwards

Haime) 1860: 127

Cönopsammia ehrenbergiana:

Dendrophyllia aurea:

Tubastraea aurea:

Tubastraea coccinea:

Tubastraea aurea: van der Horst, 1926: 46

Boschma, 1953: 112-117

Maragos, 1977: 197

Scheer \& Pillai, 1983: 173

Tubastraea aurea is a yellow-orange soft tissue coral. In the Red Sea, the species is not as common as in the Indian Ocean and Western Pacific including Hawaii. The plocoid colonies rarely exceed fist-size and usually occur clustered below overhangs and in other shaded parts of the reef. Occasionally they are found fully exposed in the Philippines.

\section{METHODS}

Tubastraea micranthus was collected at various sites off Cebu, Philippines; field studies were also undertaken at Sumilon Island (between southern Cebu and Negros) and near Puerto Galera Bay and Verde Island (between Luzon and Mindoro). T. aurea material was collected near Puerto Galera Bay. Additional material had kindly been collected by M. Plewka at Hawaii. Acropora species which served for comparison were collected at Discovery Bay, Jamaica (see Schuhmacher and Plewka, 1981a).

In order to assess the mechanical resistance of the skeleton, the following parameters were measured: porosity, compressive strength, bending strength, elastic modulus and resistance against abrasion. Since these properties strongly depend on the porosity, this feature was examined in each probe before other measurements were undertaken.

Tests were performed following standards of the German Governmental Material Testing Bureau and using the respective devices. Total porosity, i.e. the share of all voids in the total volume of a probe, was

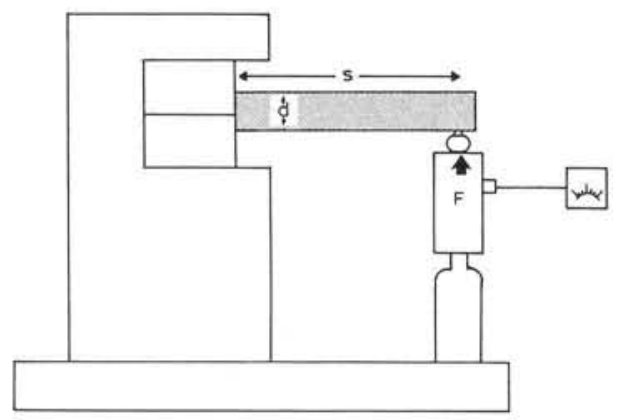

Fig. 2. Device for measuring bending strength. Stippled: coral beam fixed at left end; $F=$ bending force generated by hydraulic press; $\mathrm{s}=$ distance between point of exertion of $\mathrm{F}$ and point of breakage; $\mathrm{d}=$ diameter of coral branch

found by using buoyancy techniques and calculations based on the specific gravity of aragonite. In order to evaluate the compressive strength of the skeleton, cubic prisms $(12 \times 12 \times 24 \mathrm{~mm})$ were exposed to increasing hydraulic compression until collapse in the testing machine, Zwick 1387 . The elastic modulus was measured with the E-G-Meter after Kottas, 9,000. These methods are described in Schuhmacher and Plewka (1981a). The bending strength was evaluated by measuring the force acting upon a cantilevered cylindrical branch of $10-12 \mathrm{~cm}$ length at rupture (Fig. 2).

The bending force $(\sigma)$ was calculated from

with $\quad \mathrm{M}=\mathrm{F} \cdot \mathrm{s}$ and $\mathrm{W}=\frac{\mathrm{I}}{\frac{\mathrm{d}}{2}}$

$$
\begin{aligned}
& \sigma=\frac{M}{W} \\
& M=F \cdot s \text { and } W=\frac{I}{\frac{d}{2}}
\end{aligned}
$$

For F, s and d see Fig. 2. I, the momentum of inertia, depends on the geometry of the probe, in case of a cylinder

$$
\mathrm{I}_{\text {geom }}=\frac{\pi \cdot d^{4}}{64}
$$

Since the porosity of the material reduces the real sectional area, the real momentum of inertia is approximated by

$$
I_{\text {real }}=I_{\text {geom }} \cdot \frac{(100-P)}{100}
$$

with $\mathrm{P}=$ porosity in percent.

Small-scale differences of porosity between central and peripheral parts of the branch cross section were neglected. They are not as pronounced as in the basal parts of a colony.

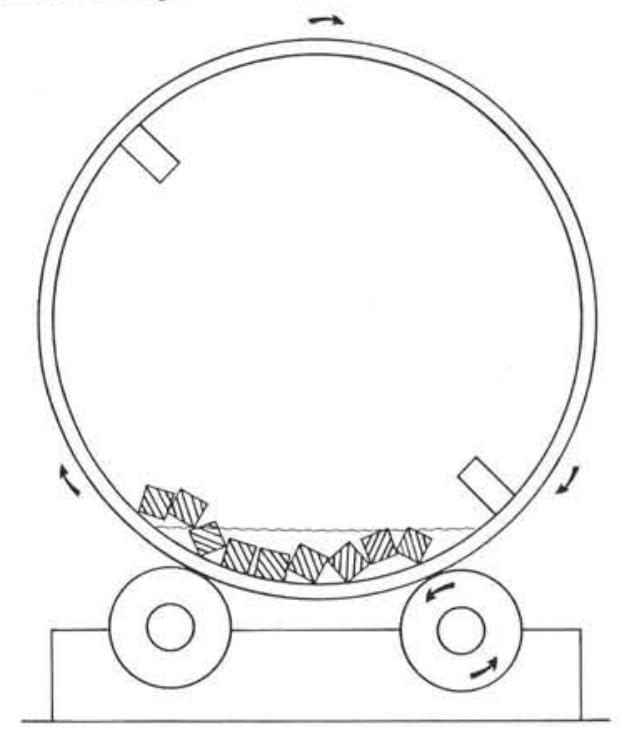

Fig. 3. Rotating cylinder; driving gear is at right (arrows). Hatched: coral cubes in water 
Resistance to abrasion was measured in a rotating container (Fig. 3). This device simulates the fate of broken pieces when rolled by currents over the reef. Relative loss by abrasion is another measure of skeleton durability. It depends directly on the porosity of the material. Cubic prisms of $2 \mathrm{~cm}$ edge length were cut in Tubastraea micranthus and $T$. aurea from basal portions of a colony, in Acropora palmata from thick branches. Cylindrical prisms of $2 \mathrm{~cm}$ length and diameter were obtained by cutting up appropriate branches of $T$. micranthus and A. cervicornis. Fragile prominences of the surface (e.g. side buds and corallites) had been removed before in order not to bias the results. The probes, 10 to 12 specimens per run, were rolled over distances of 5,000 and $10,000 \mathrm{~m}$.

\section{RESULTS}

Porosity of Tubastraea micranthus skeletons increases considerably from colony base to branch tips. This is due to: (a) greater ratio of corallite-volume/ coenosteum at the colony's distal ends, where the coenosteum is not yet thickly developed; (b) subsequent filling of pores due to carbonate deposition by the deeply 'rooted' calicoblastic layer. This solidification becomes particularly evident at the colony base. Here the porosity of the coenosteum decreases from 25 to $35 \%$ at the periphery to no more than $16 \%$ in the core (Fig. 4).

The Tubastraea aurea skeleton lacks a coherent coenosteum. Consequently, its porosity was determined by the void of the corallites. Values of porosity range from 60 to $73 \%$.

Resistance to abrasion and compressive strength were measured in all 4 species. Bending strength and elastic modulus are ecologically irrelevant for the plocoid Tubastraea aurea. Beyond that it would have been impossible to prepare equal-sized probe-speci-

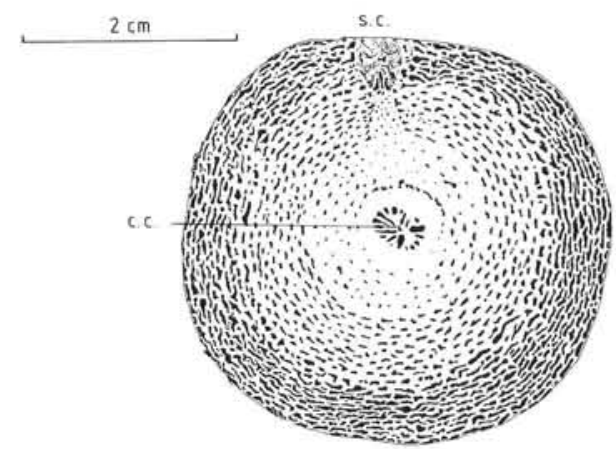

Fig. 4. Tubastraea micranthus. Cross section of stem semidiagrammatic; note the difference in porosity between peripheral and central parts due to secondary calcification. s.c.: side corallite; c.c.: central (primary) corallite

mens as used for the other species. Therefore, $T$. aurea was not considered with regard to bending forces. Resistance to abrasion of the 4 species is shown in Table 1 . The material loss by rolling over 5,000 and $10,000 \mathrm{~m}$ was comparably low in $T$. micranthus and Acropora cervicornis, when cylindrical prisms were tested. Comparison of $T$. micranthus with $T$. aurea and A. palmata, based on cubic prisms, showed that $T$. micranthus is most resistant to abrasion, followed by $A$. palmata and - by a wide margin - by $T$. aurea.

Differences in porosity and abrasive resistance between cubic and cylindrical prisms of Tubastraea micranthus exist, because cubic probes were cut from the solidified base, whereas cylindrical probes were cut from middle portions of branches where the coenosteum is still relatively porous. The compressive strength of the 4 species is shown in Fig. 5a. T. micranthus turned out to be significantly stronger than $A$. cervicornis; both were stronger than A. palmata (Acropora data are from Schuhmacher and Plewka, 1981a). Compared to these species, $T$. aurea is very weak. Porosity and compressive strength are inversely correlated.

Bending strength is the mechanical property which

Table 1. Mean material loss due to abrasion

\begin{tabular}{|c|c|c|c|c|c|}
\hline Species & $\begin{array}{l}\text { Number of } \\
\text { test pieces }\end{array}$ & $\begin{array}{l}\text { Probe } \\
\text { geometry }\end{array}$ & $\begin{array}{c}\text { Porosity } \\
\%\end{array}$ & $\begin{array}{c}\text { Abrasion } \\
\text { after } 5,000 \mathrm{~m} \\
\%\end{array}$ & $\begin{array}{c}\text { Total abrasion } \\
\text { after } 10,000 \mathrm{~m} \\
\%\end{array}$ \\
\hline Tubastraea micranthus & 12 & $\begin{array}{l}\text { Cylindrical } \\
\text { prisms, } 2 \mathrm{~cm} \varnothing\end{array}$ & 28.9 & 4.5 & 7.2 \\
\hline Acropora cervicornis & 20 & $\begin{array}{l}\text { Cylindrical } \\
\text { prisms, } 2 \mathrm{~cm} \varnothing\end{array}$ & 24.4 & 4.5 & 7.0 \\
\hline Acropora palmata & 100 & $\begin{array}{l}\text { Cubic prisms } \\
2 \mathrm{~cm} \text { edge length }\end{array}$ & 35.5 & 4.6 & 7.6 \\
\hline Tubastraea micranthus & 12 & $\begin{array}{l}\text { Cubic prisms } \\
2 \mathrm{~cm} \text { edge length }\end{array}$ & 16.5 & 3.2 & 5.4 \\
\hline Tubastraea aurea & 12 & $\begin{array}{l}\text { Cubic prisms } \\
2 \mathrm{~cm} \text { edge length }\end{array}$ & 63.5 & 35.0 & 45.5 \\
\hline
\end{tabular}


Fig. 5. Mechanical properties of Tubastraea and Acropora test specimens. (a) Compressive strength; (b) bending strength; (c) elastic modulus. Acropora-data are from Schuhmacher and Plewka (1981a)

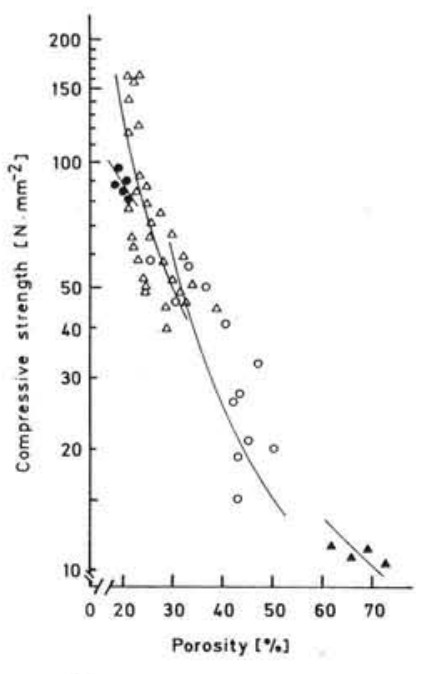

a

is most important in branching colonies. Unlike bushy corals of the Stylophora- or Pocillopora-type, Tubastraea micranthus, Acropora cervicornis and A. palmata colonies extend far into the water current. As shown in Fig. 5b, the bending strength of $T$. micranthus is significantly higher than that of the Acropora species examined. This is especially noteworthy, because the relatively large and irregularly dispersed corallites may be thought to favour premature fractures. Measurements of elastic modulus underline the relative strength of $T$. micranthus (Fig. $5 \mathrm{c}$ ): its skeleton can absorb more strain energy per unit volume than that of $A$. cervicornis and A. palmata.

Porosity-dependent differences in mechanical properties of Tubastraea micranthus, Acropora cervicornis and A. palmata are accounted for when pieces of identical porosity are compared (Table 2). In spite of the small number of replicates, the data suggest that the specific microarchitecture of $T$. micranthus results in a better skeletal bond than that of the Acropora specimens.

\section{DISCUSSION}

Comparative studies of reef-building corals possessing zooxanthellae (hermatypic sensu Wells) (Schuhmacher, in prep.) show that Acropora species

- Tubastraea micranthus

- Tubastraea aurea

- Acropora palmata

$\triangle$ Acropora cervicornis

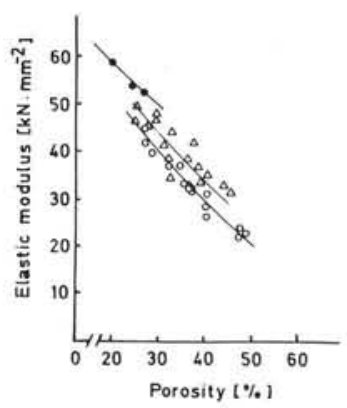

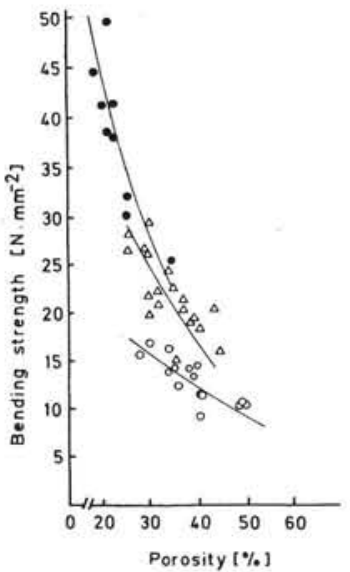

b rank at the high-strength end of the porosity/strength continuum. Therefore, in the present comparison of 'ahermatypic' and 'hermatypic' corals the 2 Acropora species can be regarded as having high mechanical properties, necessary to erect a durable framework. Tubastraea micranthus equals or even surpasses the skeletal strength of $A$. cervicornis. In contrast, $T$. aurea is characterized by much lower strength values than the Acropora species.

The skeletal weakness of Tubastraea aurea is generally expected from an 'ahermatypic' coral. It should be mentioned here that some 'hermatypic' species, such as Colpophyllia natans (Müller), Pectinia lactuca (Pallas) and Euphyllia glabrescens (Chamisso and Eysenhardt), rank similar or even lower than $T$. aurea (Schuhmacher, in prep.). A detailed discussion of this phenomenon is beyond the scope of this paper. On the other hand, the superior material properties of $T$. micranthus are noteworthy. They are due to low porosity and, most likely, to a specific microarchitecture, not yet analysed.

The colony's mechanical strength is supplemented by a shape advantageous to counter high bending forces: the stem is broadened at its base, where the bending momentum is highest. Schuhmacher and Plewka (1981a) documented the significance of this morphological adaptation. Infestation by boring

Table 2. Comparison of skeletal strength at the same porosity $(25 \%)$

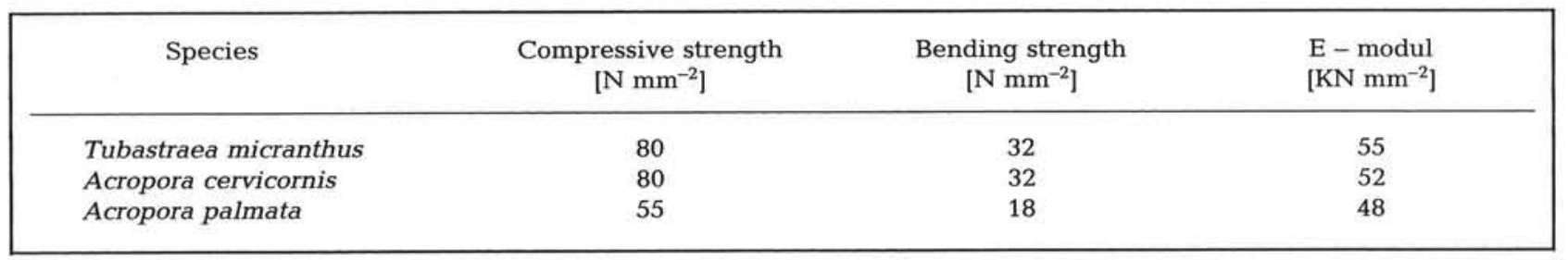


sponges, which often weaken the colony base, is extremely low in Tubastraea micranthus. Hence this species is designed well to withstand hydrodynamic attacks and to colonize a current-exposed habitat. In fact, only $T$. micranthus colonies, 60 to $90 \mathrm{~cm}$ high, remained erect in dynamite-blasted reef parts at Sumilon Island. Near Verde Island (Puerta Galera Bay), $T$. micranthus colonies were found in 5 to $8 \mathrm{~m}$ water depth on the tops of uprising rocks, where currents of $1 \mathrm{~m} \mathrm{~s}^{-1}$ were recorded. In this position, a solid foothold as well as a durable stand in the current are necessary. $T$. micranthus is completely dependent on food carried by the water.

The polyps expand at night, spanning up to $3 \mathrm{~cm}$. They were observed to catch large planktonic organisms such as salps and polychaetes (up to several $\mathrm{cm}$ long). Tubastraea micranthus grows longitudinally at a rate of $4 \mathrm{~cm} \mathrm{yr}^{-1}$ (Drs Wellington and Trench, pers. comm.); this is remarkable for a coral without symbiotic algae, but nevertheless relatively slow compared to the rate of up to $12 \mathrm{~cm} \mathrm{yr}^{-1}$ in branching acroporids (Gladfelter et al., 1978).

Tubastraea micranthus does not conform with the conventional conception of an 'ahermatypic' coral except for being devoid of zooxanthellae. The large and robust colonies rather represent what Goreau (1963) and Goreau and Goreau (1973) distinguished as primary framework-builders. These authors described another category of corals as secondary hermatypes, which are more fragile and tend to fill the interstices between the present frame. Hence $T$. micranthus, a morphological frame-builder, should be affiliated with the 'hermatypic' rather than the 'ahermatypic' corals, in the literal sense (presence or absence of zooxanthellae not taken into account).

Wells (1933) also used the bathymetric range as another criterium to distinguish 'hermatypic' and 'ahermatypic' corals. Again, Tubastraea micranthus fits into the 'hermatypic' type. It was never observed or dredged from really deep water - the 'classic' realm of the 'ahermatypes'. For example, an extensive survey of the upper $200 \mathrm{~m}$ of the coastal slope by a submersible in the Gulf of Aqaba showed that $T$. micranthus and $T$. aurea occurred closer to the surface than Leptoseris spp. and ecologically similar coral species possessing zooxanthellae (Fricke and Schuhmacher, 1983). In addition, SCUBA investigations down to $70 \mathrm{~m}$ off Port Sudan did not record the 2 Tubastraea species between 20 and $70 \mathrm{~m}$ (Kühlmann, 1983).

Tubastraea micranthus, as well as $T$. aurea, lack zooxanthellae which are considered a prerequisite of a reef-builder: 'Reef-building (hermatypic) corals are inevitably associated with the endosymbiotic dinoflagellate Gymnodinium microadriaticum' (Chalker, 1976). Acquisition of zooxanthellae, with the side effect of enhanced calcification, was most probably the major factor for the evolutionary success and geomorphological importance of scleractinians (e.g. Goreau, 1959; Schuhmacher, 1976; Muscatine and Porter, 1977; Stanley, 1981). In fact, zooxanthellae-driven calcification enables rapid compensation of losses caused by hydrodynamic destruction. But the integration of a symbiotic pacemaker for enhanced calcification is not the only strategy for attaining reef-building capacities. The present study shows that there is still the option of uncompromised augmentation of skeletal strength. Long-lasting, high resistance to hydrodynamic stress is derived from a maximal solidified skeleton - most likely at the expense of growth. Presumably, this strategy was common among ancient reef-builders (Schuhmacher and Plewka, 1981b).

Tubastraea micranthus can be regarded as one of the few recent pursuers of this evolutionary route. Its constructional role on the reefs of the Philippines and adjacent waters qualifies this species as reef-building. Therefore, $T$. micranthus is 'hermatypic' in the strict sense of the word without requiring the support of zooxanthellae. There is growing disagreement with the conventional definition of 'hermatypic' and 'ahermatypic' (Rosen, 1981; Fricke and Schuhmacher, 1983). This paper emphasizes the necessity to reconceptualize this problem.

Acknowledgements. I thank Mrs. K. Pferdehirt for skillfull measurements. The 'Staatliches Materialprüfungsamt, Dortmund', kindly provided technical advice and access to testing machines. Dr. H. Zibrowius made helpful suggestions. This research project was funded by 'Deutsche Forschungsgemeinschaft' and, in part, by 'Stiftung Volkswagenwerk'.

\section{LITERATURE CITED}

Boschma, H. (1953). On specimens of the coral genus Tubastraea, with notes on phenomena of fission. Stud. Fauna Curaçao and other Caribb. Islands 4: 109-119, pls. 9-12

Chalker, B. E. (1976). Calcium transport during skeletogenesis in hermatypic corals. Comp. Biochem. Physiol. 54 A: 455-459

Chamberlain, J. A., Jr. (1978). Mechanical properties of coral skeleton: compressive strength and its adaptive significance. Paleobiol. 4: 419:435

Crossland, C. (1952). Madreporaria, Hydrocorallinae, Heliopora and Tubipora. Scient. Rep. Gt Barrier Reef Exped. 1928-1929. 6: 85-257, pls. 1-56

Dana, J. D. (1846). Zoophytes. U. S. exploring expedition during the years 1838-1848 under the command of Charles Wilkes. U.S.N. 7: 740 pp. 61 pls. Philadelphia (1846-1848 Atlas 1849)

Ehrenberg, C. G. (1834). Beiträge zur physiologischen Kenntniss der Corallenthiere im allgemeinen, und besonders des rothen Meeres, nebst einem Versuch zur physiologischen Systematik derselben. Phys. Abh. Königl. Akad. Wissensch. Berlin 1832: 225-380 
Faustino, L. A. (1927). Recent Madreporaria of the Philippine Islands. Monogr. Bur. Sci. Manila 22. 310 pp., pls. 1-100

Fricke, H. W., Schuhmacher, H. (1983). The depth limits of Red Sea stony corals: an ecophysiological problem (A deep diving survey by submersible). P.S.Z.N.I. Mar. Ecol. 4: 163-194

Gladfelter, E. H., Monahan, R. K., Gladfelter, W. B. (1978). Growth rates of five reef-building corals in the Northeastern Caribbean. Bull. mar. Sci. 28: 728-734

Goreau, T. F. (1959). The physiology of skeleton formation in corals, I. A method for measuring the rate of calcium deposition by corals under different conditions. Biol. Bull. mar. biol. Lab., Woods Hole 116: 50-59

Goreau, T. F. (1963). Calcium carbonate deposition by coralline algae and corals in relation to their roles as reefbuilders. New York Acad. Sci. Ann. 109: 127-167

Goreau, T. F., Goreau, N. I. (1973). The ecology of Jamaican coral reefs. II. Geomorphology, zonation, and sedimentary phases. Bull. mar. Sci. 23: 399-464

Graus, R. R., Chamberlain, J. A., Jr., Boker, A. M. (1977). Structural modification of corals in relation to waves and currents. Stud. Geol. 4 : 135-153

v. d. Horst, C. J. (1922). The Madreporaria of the Siboga Expedition. III. Eupsammidae. Monogr. Siboga-Exped. 16c: 99-127, pls. 7, 8

v. d. Horst, C. J. (1926). Madreporaria: Eupsammidae (Percy Sladen Trust Expedition to the Indian Ocean in 1905). Trans. Linn. Soc. London, 2nd ser. Zool. 19: 43-53, pls. 2, 3

Klunzinger, C. B. (1879). Die Korallthiere des Rothen Meeres. 2: Die Steinkorallen. 1. Abschn.: Madreporaceen und Oculinaceen. Verlag der Gutmann'schen Buchhandlung, Berlin

Kühlmann, D. (1983). The composition and ecology of deepwater coral associations. Helgoländer Meeresunters. 36: 183-204

Lesson, R. P. (1834). Zoophytes. In: Voyage aux Indes Orientales par le nord de l'Europe pendant 1825-1829 de Ch. Belanger, Zool: 505-519, pls. 1, 2, Paris

Maragos, J. E. (1977). Scleractinia. In: Devaney, D. M., Eldredge, L. G. (ed.) Reef and shore fauna of Hawaii. Section 1: Protozoa through Ctenophora. Bishop Museum Press, Honolulu, p. 158-241

Milne Edwards, H. (\& Haime, J.) (1860). Histoire naturelle des coralliaires. Tome 3 . Paris
Muscatine, L., Porter, J. W. (1977). Reef corals: mutualistic symbioses adapted to nutrient-poor environments. Bioscience 27: 454-460

Nemenzo, F. (1960). Systematic studies on Philippine shallow water scleractinians. IV: Suborder Dendrophylliidae. Nat. Appl. Sci. Bull. Univ. Philipp. 18: 1-21, pls. 1-10

Pichon, M. (1978). Recherches sur les peuplements à dominance d'anthozoaires dans les récifs coralliens de Tuléar (Madagascar) Atoll Res. Bull. 222: 1-447

Quoy, J. R. C., Gaimard, J. P. (1833). Zoophytes. Voyage des découvertes de l'Astrolabe. Zool. 4: 360 pp., pls. 26 (in atlas), Paris

Rosen, B. R. (1979). Check list of recent coral records from Aldabra (Indian Ocean). Atoll Res. Bull. 233: 1-24

Rosen, B. R. (1981). The tropical high diversity enigma - the corals'-eye view. In: Forey, P. L. (ed.) Chance, change and challenge. The evolving biosphere. British Museum (Nat. Hist.) and Cambridge University Press, p. 103-129

Scheer, G., Pillai, C. S. G. (1983). Report on the stony corals of the Red Sea. Zoologica 133: 1-198, pls. 1-41

Schuhmacher, H. (1976). Korallenriffe durch Recycling. Umschau 15: 491-493

Schuhmacher, H. (1981). Die Festigkeit von Korallenskeletten - ein bisher unbeachteter Parameter beim Riffaufbau. Verh. dt. zool. Ges. 1981: 154

Schuhmacher, H., Plewka, M. (1981a). The adaptive significance of mechanical properties versus morphological adjustments in skeletons of Acropora palmata and Acropora cervicornis (Cnidaria, Scleractinia). Proc. Fourth Int. Coral Reef Symp., Manila, Vol. 2: 121-128

Schuhmacher, H., Plewka, M. (1981b). Mechanical resistance of reef builders through time. Oecologia 49: 279-282

Stanley, G. D., Jr. (1981). Early history of scleractinian corals and its geological consequences. Geology 9: 507-511

Tunnicliffe, V. (1979). The role of boring sponges in coral fracture. In: Biologie des spongiaires. Colloques internationaux du C.N.R.S. No. 291: 309-315

Vaughan, T. W., Wells, J. W. (1943). Revision of the suborders, families, and genera of the Scleractinia. Spec. Pap. Geol. Soc. Am. 44: 363 pp., pls. 1-51

Wells, J. W. (1933). Corals of the Cretaceous of the Atlantic and Gulf Coastal Plains and western interior of the United States. Bull. Am. Paleont. 18: 85-288 